\title{
Pengembangan Branding dan Pelatihan Pemanfaatan Teknologi Informasi pada Usaha Jus Buah
}

\author{
Ricky Aurelius Nurtanto Diaz ${ }^{1}$, Putu Devi Novayanti ${ }^{2}$, I Made Suandana Astika Pande ${ }^{3}$, \\ Komang Wirayudha Wizu Diaz ${ }^{4}$, Ayu Ratih Cantika Dewi ${ }^{5}$ \\ ricky@stikom-bali.ac.id ${ }^{1}$, devinovayanti@stikom-bali.ac.id², suandana@stikom-bali.ac.id ${ }^{3}$, \\ yudhadiaz02@gmail.com ${ }^{4}$, ayuratih23jan@gmail.com ${ }^{5}$ \\ 1,2,3,4,5 Institut Teknologi dan Bisnis STIKOM Bali
}

\begin{abstract}
Article History:
Received: 15-04-2021

Revised: 16-06-2021

Accepted: 17-07-2021
\end{abstract}

\begin{abstract}
The COVID-19 pandemic has caused many changes in people's daily lives. Various ways have been carried out in dealing with this pandemic, like use masks, diligently washing hands and, eating balanced nutrition. The pandemic condition has also raised many new entrepreneurs in various fields. Noona Juice, which is engaged in pure fruit juice, is a form of business that arises due to economic demands and opportunities for increasing public demand for nutritious food and drinks. The condition that occurs to the business of internal community service partners is the lack of an existing market because the marketing process is only carried out through relatives or family contacts and is produced according to the number of orders. Seeing the opportunities that exist for partners, from these conditions the purpose of this community service activity is to help partners in developing their business brands and also assist partners in utilizing financial technology. To achieve this goal, the service team will provide training and workshops in developing partner business branding, online marketing training, and training on the use of financial technology. From the evaluation of the activities that have been carried out, partners are satisfied with the activities that have been carried out.
\end{abstract}

\section{Pendahuluan}

Pandemi COVID-19 atau yang dikenal dengan Corona virus menyebabkan banyak perubahan yang terjadi dalam kehidupan masyarakat sehari-hari. Berbagai cara baik dari pemerintah, swasta maupun swadaya masyarakat dilakukan dalam menghadaoi kondisi pandemi ini mulai dari seruan untuk selalu menggunakan masker, rajin cuci tangan sampai dengan menjaga kesehatan dengan cara makan teratur dan gizi seimbang. Gizi yang baik memang sangat dibutuhkan sebelum, selama atau setelah seseorang terkena infeksi, dimana saat tubuh terkena infeksi, maka tubuh akan menjadi demam (Kemenkes, 2020). Disinilah pentingnya tambahan energi dan gizi. Meskipun sampai saat ini belum ada informasi makanan atau suplemen makanan yang dapat mencegah infeksi COVID-19, namun disadari bahwa mempertahankan pola makan gizi seimbang yang sehat sangat penting dalam upaya meningkatkan sistem kekebalan tubuh. Kesadaran masyarakat akan pentingnya gizi seimbang ini menyebabkan juga mulai meningkatnya permintaan akan 
berbagai jenis makanan sehat termasuk buah yang dikemas dalam bentuk buah potong maupun yang dijadikan juice atau smoothies.

Kegiatan pengabdian masyarakat ini akan membantu salah satu mitra yang memproduksi dan menjual jus buah murni. Kondisi yang terjadi dilapangan saat ini adalah dimana mitra yang berlokasi di Jalan Serma Gede Nomor 13 Denpasar merupakan mitra pengabdian masyarakat internal yang memasarkan juice buah melalui kontak kerabat atau keluarga dan diproduksi sesuai pesanan. Usaha juice buah ini dimulai semenjak adanya pandemi untuk membantu dalam keuangan keluarga dan berlangsung sampai saat ini. Mitra memiliki jumlah produksi dan penjualan yang tidak pasti karena disesuaikan dengan jumlah pesanan. Kendala yang terjadi adalah saat ini mitra belum memiliki konsep pemasaran yang cukup baik, sehingga produk yang dihasilkan hanya diketahui oleh kerabat dekat dan masyarakat sekitar. Mitra juga mengalami kendala dalam pemesanan jumlah besar yang dilakukan dalam waktu dekat, karena sarana produksi yang terbatas. Tingkat pengetahuan mitra yang cukup minim tentang branding terlihat dari label nama usaha yang telah coba dibuat sendiri namun dianggap masih kurang menarik dan menjual. Kegiatan pengabdian ini rencananya akan memberikan pelatihan ke mitra untuk label kemasan dan untuk mempercepat informasi sampai ke masyarakat dengan meningkatkan branding produk yang dijual oleh mitra. Pentingnya kemasan dalam suatu usaha telah banyak menjadi saran dari para peneliti dan maupun tim pengabdian seperti yang pernah dipublikasikan oleh (Putri, Suniantara, \& Suardika, 2019) yang mengangkat topik mengenai kemasan produksi urutan Bali home industry. Yana Erlyana juga pernah membahas mengenai peranan penting desain kemasan terhadap brand identity produk makanan lokal (Erlyana, 2018). Begitu juga dengan Desi Saryanti beserta tim yang pernah membahas mengenai pengembangan dan pemanfaatan desain kemasan sebagai media promosi (Saryanti, Mandasari, \& Sidhiantari, 2020).

Disisi lain, selama ini mitra tidak melakukan pencatatan dan perhitungan mengenai jumlah penjualan, data customer, maupun pendapatan bersih yang diperoleh. Dalam upaya memasarkan produk, diperlukan komunikasi pemasaran yang baik (Diaz, Harsemadi, Arini, Sulistyorini, \& Wedasari, 2019). Bagi perkembangan komunikasi pemasaran, media sosial memungkinkan peningkatan nilai (value) dari para pelakunya, dengan menggunakan prinsip membangun relasi antara perusahaan dengan followers atau fans (Arisandi \& Pradana, 2018). Untuk itu, maka dalam kegiatan pengabdian ini tim pengabdian akan memberikan pelatihan dan workshop dalam pengembangan branding usaha mitra, pelatihan pemasaran secara online khususnya melalui media sosial, serta pelatihan penggunaan tekologi keuangan. Tujuan kegiatan ini agar memberikan peningkatan brand awareness terhadap produk yang dijual mitra, serta adanya pencatatan yang baik dalam sisi keuangan dan data 
ADMA

Gurnal Pengabdian dan Pemberdayaan Masyarakat
2021, Vol.2, No.1, pp.1-10

Doi: 10.30812/adma.v2i1.1165

terkait lainnya.

\section{Metode}

Solusi yang ditawarkan dari permasalahan yang telah dijabarkan adalah pelatihan dalam pengembangan brand awareness dan pelatihan dalam penggunaan teknologi keuangan. Peningkatan branding usaha, difokuskan dalam desain label kemasan dan optimalisasi dalam peningkatan brand awareness khususnya dalam media online. Pelatihan penggunaan teknologi keuangan difokuskan untuk membantu mitra dalam mendokumentasikan transaksinya serta untuk mengetahui laba atau rugi usaha mitra dengan lebih mudah. Adapun kegiatan yang dilaksanakan digambarkan pada gambar 1 :

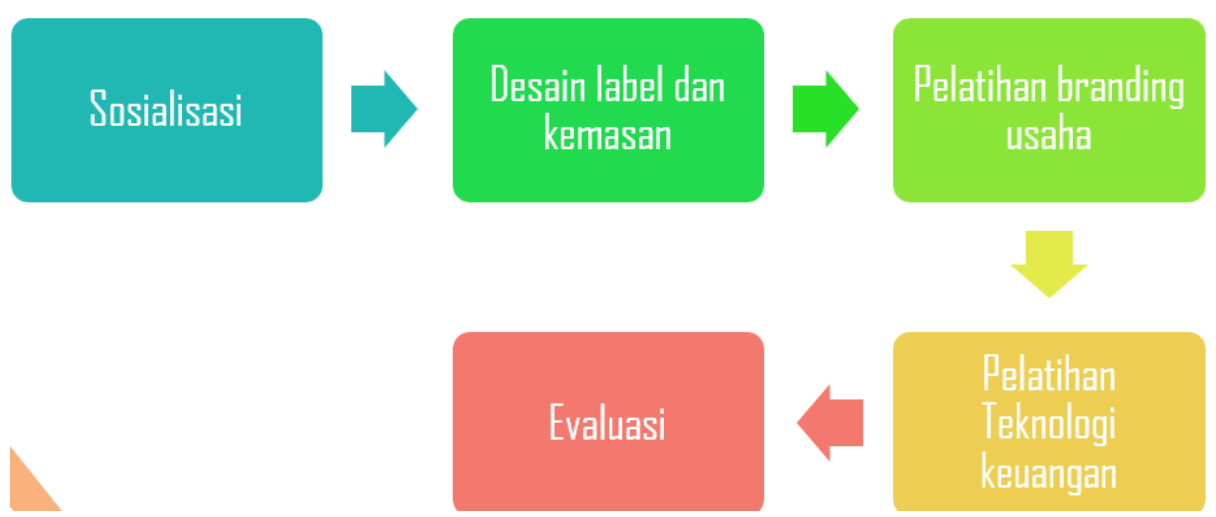

Gambar 1. Proses pelaksanaan pengabdian

Dalam kegiatan pengabdian masyarakat ini memiliki beberapa tahapan yang dilakukan agar sesuai dengan solusi atas permasalahan yang diinginkan. Dalam kegiatan pengabdian ada beberapa tahapan yang dilakukan oleh tim pengabdian masyarakat dengan tahap sebagai berikut:

\section{1) Sosialisasi kegiatan}

Tahapan pertama yang dilakukan adalah dengan melakukan kegiatan sosialisasi untuk memberikan gambaran kepada mitra mengenai kegiatan pengabdian masyarakat. Dalam tahap ini disampaikan tim yang terlibat, proses dan tahap-tahap yang dilakukan serta kesepakatan mengenai jadwal pelatihan yang akan dilakukan.

\section{2) Desain label dan kemasan}

Tahapan ini dilakukan antara tim pengabdian masyarakat bersama dengan mitra dalam mencari bentuk desain label dan kemasan yang sesuai dengan keinginan mitra dan juga sesuai atau menarik dalam sisi branding. Untuk itu dalam tahap ini, mitra tidak dibiarkan sendirian memutuskan bentuk desain label atau kemasan, namun diarahkan dan dibuat oleh tim pengabdian masyarakat. 
3) Pelatihan Branding Usaha

Tahap ini difokuskan pada pengembangan branding usaha yang dibangun oleh mitra. Fokus dalam tahap ini adalah melatih mitra dalam pengelolaan brand dan meningkatkan brand awareness masyarakat, sehingga dapat menunjang usaha mitra dalam mencapai target pasar yang lebih luas, dan tentunya jumlah pesanan yang meningkat seiring meluasnya target pasar mitra.

4) Pelatihan Teknologi Keuangan

Tahapan ini ditujukan untuk membantu mitra dalam mengelola usahanya dengan lebih tertata dengan bantuan teknologi, karena sampai saat ini mitra tidak mencatat dengan detail setiap transaksi baik pengeluaran maupun pemasukan. Diharapkan dengan pelatihan penggunaan teknologi keuangan, segala transaksi yang dilakukan mitra dapat terdokumentasi dengan baik.

5) Evaluasi kegiatan

Evaluasi kegiatan merupakan tahap akhir yang akan dilakukan dalam kegiatan pengabdian masyarakat ini. Evaluasi dilakukan untuk mengukur pemahaman mitra terhadap pelatihan yang dilakukan. Pengukuran akan dilihat dari berbagai aspek yaitu jumlah pasar yang meningkat serta efektivitas penggunaan desain serta teknologi yang diperoleh mitra.

\section{Pembahasan}

Berdasarkan jadwal yang direncanakan sebelumnya, maka pada tahap awal kegiatan pengabdian ini, difokuskan pada pendampingan mitra untuk proses branding usaha yang dimiliki mitra. Kegiatan dibagi menjadi dua tahap, yaitu desain label dan branding usaha serta pelatihan branding usaha melalui media sosial. Tahap berikutnya adalah pelatihan pemanfaatan teknologi keuangan dan evaluasi.

\section{1) Desain Label dan Branding}

Desain kemasan dan logo kemasan dapat menjadi daya tarik iklan, dan brand awareness terhadap keputusan pembelian (Gede et al., 2021). Menyadari hal tersebut, pada tahap pengabdian ini, tim pelaksana pengabdian melakukan persiapan untuk menyediakan desain logo, desain kemasan, dan desain lain yang diperlukan oleh mitra nantinya dalam melakukan pemasaran produk. Dalam tahap ini dihasilkan beberapa desain yang selanjutnya akan didiskusikan kepada mitra. Berikut adalah proses desain dan diskusi dengan mitra terkait pemilihan warna dan logo branding. 


\section{ADMA}

Qurnal Pengabdian dan Pemberdayaan Masyarakat
2021, Vol.2, No.1, pp.1-10

Doi: $10.30812 / a d m a . v 2 i 1.1165$

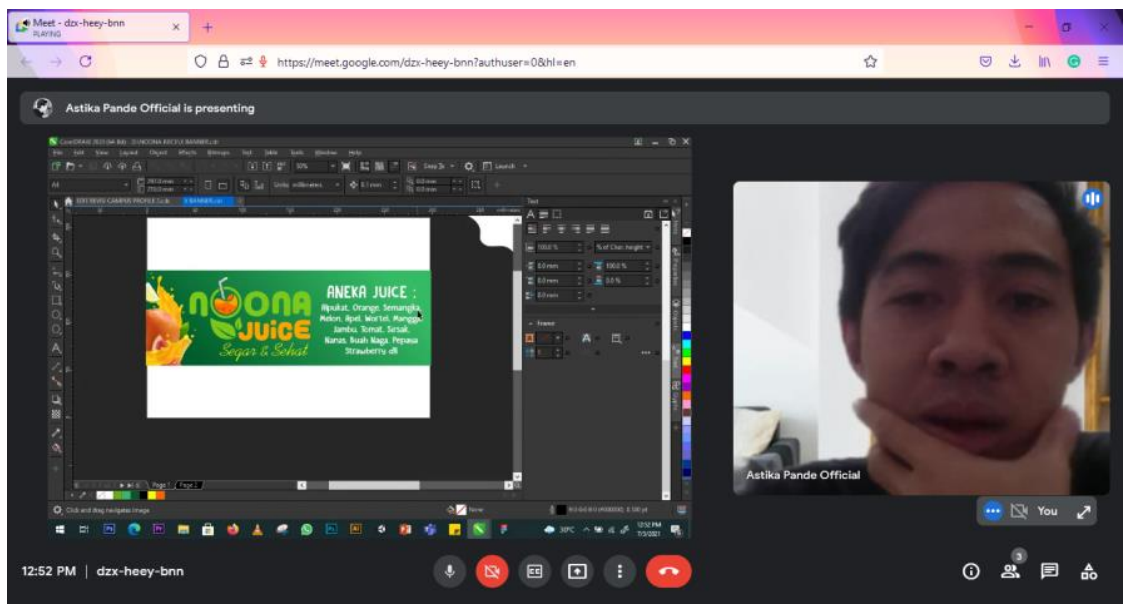

Gambar 2. Proses desain dan diskusi

Beberapa hasil desain yang dipersiapkan seperti terlihat pada gambar 3 sampai dengan gambar 6 yang merupakan desain logo tunggal yang dapat digunakan sebagai profile picture pada media sosial.

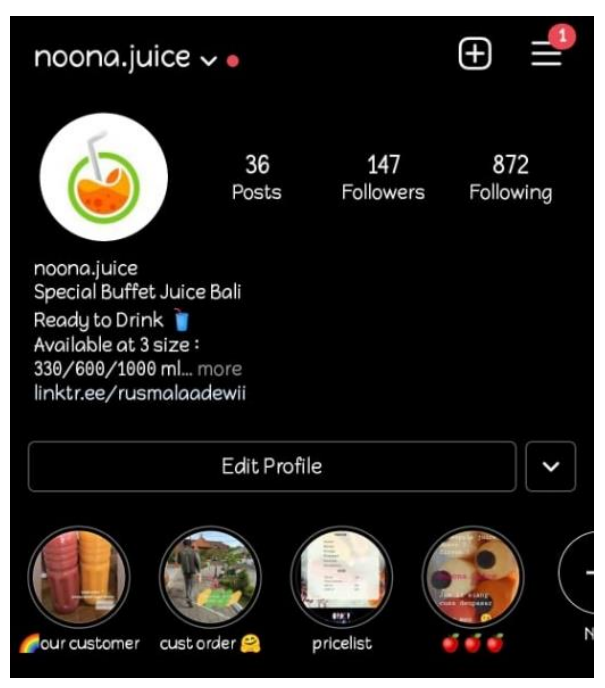

Gambar 3. Desain logo dan Implementasi pada media sosial

Selanjutnya, adalah desain logo yang lengkap untuk digunakan pada kemasan maupun perangkat lain dalam proses pemasaran yang terlihat dalam dua bentuk yaitu berwarna dan hitam putih, serta beberapa desain lain terkait branding usaha mitra.
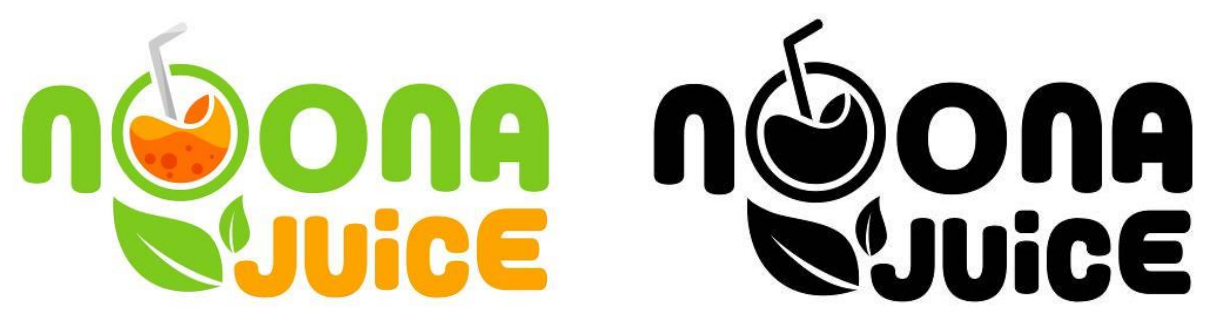

Gambar 4. Detail desain logo 


\section{ADMA}

Gernal Pengabdian dan Pemberdayaan Masyarakat
2021, Vol.2, No.1, pp.1-10

Doi: 10.30812/adma.v2i1.1165

Gambar 4 adalah bentuk desain logo yang dapat digunakan mitra untuk ditempatkan pada booth atau spanduk maupun tas belanja.
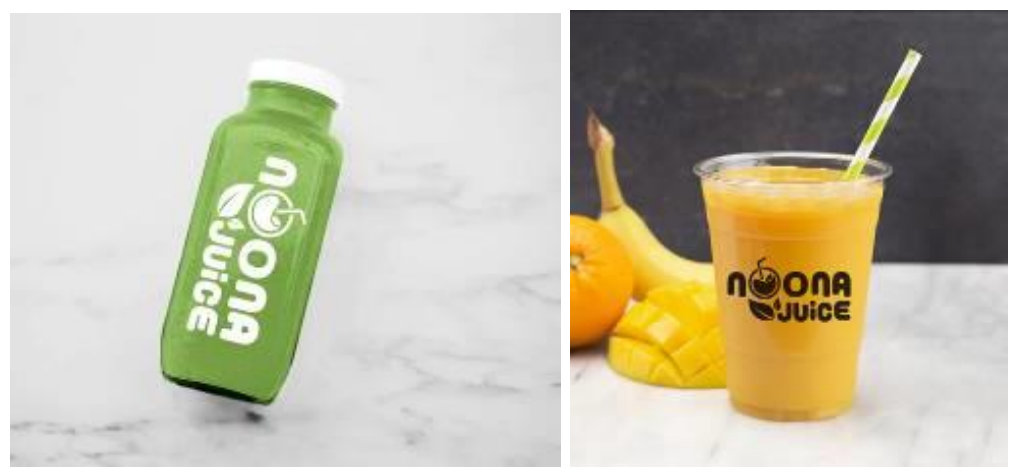

Gambar 5. Desain kemasan

Merujuk kepada salah satu inti variabel dalam brand image yaitu recognition, dimana kemampuan konsumen untuk mengingat suatu merek adalah ketika mereka melihat atau menjumpai gambar serta ciri-ciri tertentu (Agatha, Tumbel, Soepeno, Sam, \& Manado, 2019). Untuk itu, beberapa desain yang ditawarkan kepada mitra, mengarah kepada varibel recognition tersebut, seperti menyediakan bentuk desain untuk kemasan yang dapat digunakan, baik yang berbentuk botol maupun kemasan langsung minum. Selanjutnya adalah desain booth dan desain tas belanja yang dihasilkan dan dapat digunakan oleh mitra dalam menjalankan usahanya seperti terlihat pada gambar 6 .
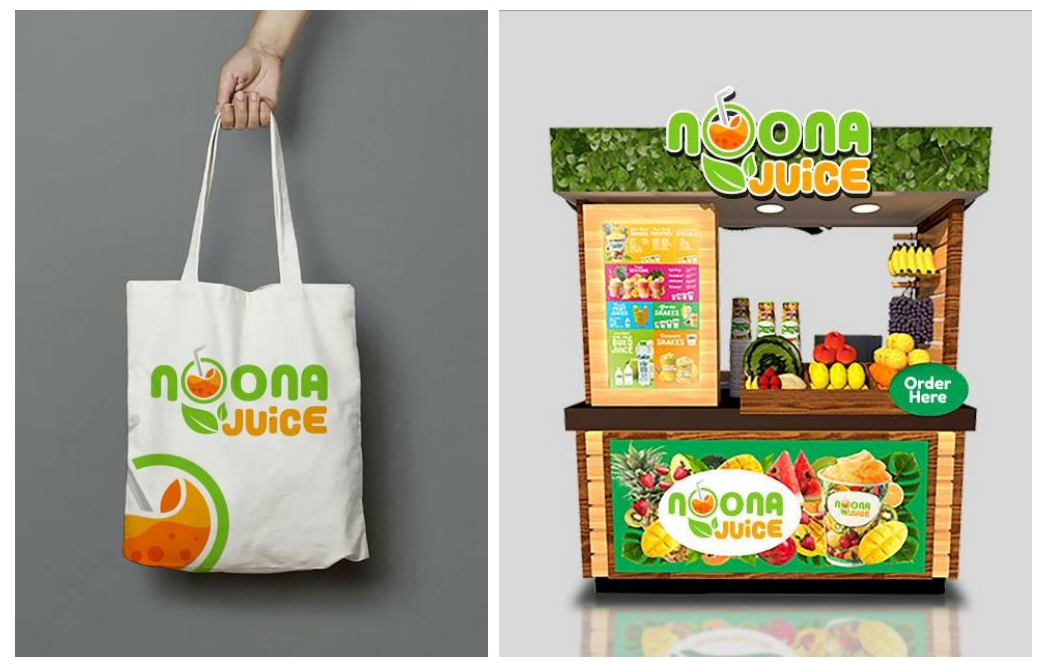

Gambar 6. Desain tas belanja dan booth

\section{2) Pelatihan Branding Usaha}

Pada tahap ini, tim pengabdian melakukan pertemuan dengan mitra secara daring. Kegiatan yang dilakukan disini adalah mengenalkan kepada mitra beberapa desain yang telah dirancang dan meminta persetujuan mitra. Disamping itu, dalam kegiatan ini juga diadakan diskusi dan pelatihan bagi mitra terkait branding usaha khususnya melalui media https://journal.universitasbumigora.ac.id/index.php/ADMA 
ADMA

Gurnal Pengabdian dan Pemberdayaan Masyarakat
2021, Vol.2, No.1, pp.1-10

Doi: 10.30812/adma.v2i1.1165

sosial. Hal ini sesuai dengan tujuan awal dari pengabdian ini agar meningkatkan brand awareness produk mitra, seperti yang pernah disampaikan oleh (Semuel \& Setiawan, 2018) sebelumnya bahwa semakin intens promosi yang dilakukan melalui media sosial, akan mendukung dalam meningkatnya brand awareness dari sebuah produk. Gambar 7 merupakan kegiatan pengabdian yang telah dilakukan:

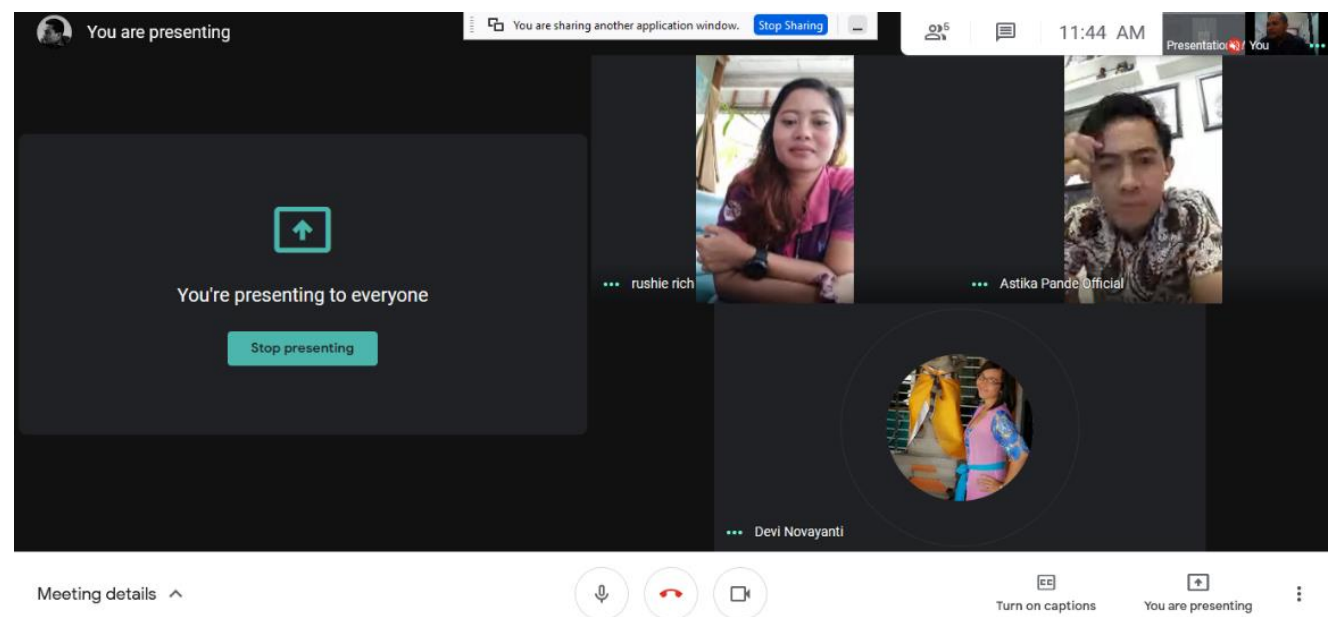

Gambar 7. Pelatihan branding usaha

\section{3) Pelatihan Pencatatan Keuangan}

Pelatihan merupakan suatu usaha dalam rangka membina tenaga kerja, yaitu ilmu pengetahuan, keterampilan, dan kemampuan seseorang dalam menjalankan usaha dan tugas-tugasnya (Anggriani, Abdurrahman, \& Ibrahim, 2021). Pada tahap ini, tim pengabdian masih melakukan pertemuan dengan mitra secara daring. Kegiatan yang dilakukan adalah pelatihan mengenai aplikasi pencatatan keuangan yaitu aplikasi Teman Bisnis, yang dapat digunakan mitra untuk mencatat data transaksinya. Disamping itu, dalam kegiatan ini juga diadakan diskusi dan workshop penggunaan aplikasi tersebut. Gambar 8 merupakan kegiatan pengabdian yang telah dilakukan:

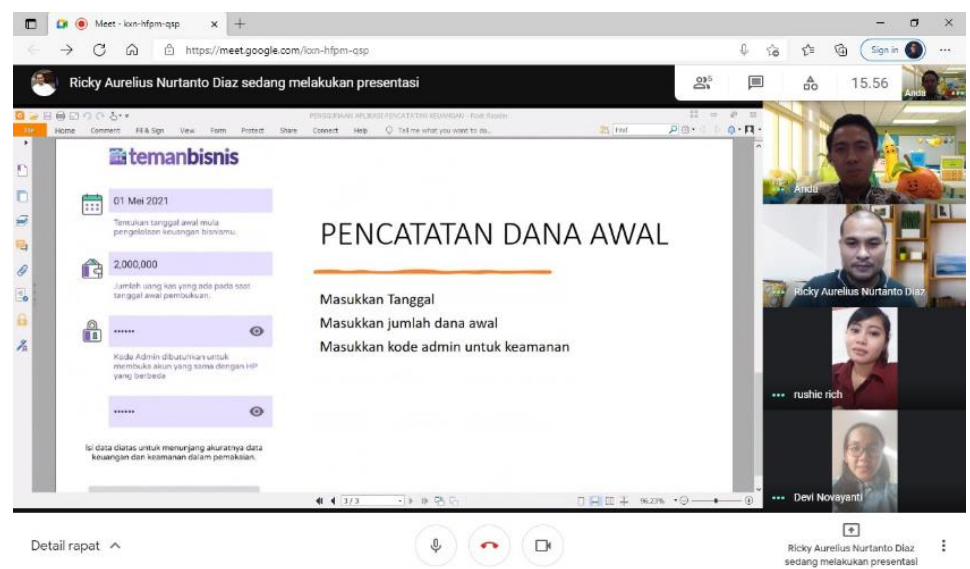

Gambar 8. Pelatihan penggunaan aplikasi pencatan keuangan 


\section{Kesimpulan}

Secara keseluruhan kegiatan pengabdian ini telah berjalan dengan baik. Pada tahap pertama, kegiatan berfokus pada proses pemasaran. Proses pengabdian pada tahap pertama ini menghasilkan desain logo dan kemasan yang dapat digunakan oleh mitra untuk memperkenalkan produk noona juice. Dengan adanya beberapa desain pemasaran, dapat memberikan kemudahan untuk mitra dalam memperkenalkan produknya. Dengan demikian usaha pemasaran dapat dilakukan melalui media sosial ataupun melalui offline menjadi lebih optimal. Tahap kedua dilanjutkan dengan pelatihan teknologi keuangan menggunakan aplikasi teman bisnis, yang dapat membantu mitra dalam pencatatan dan pengelolaan transaksi. Pada saat evaluasi, mitra memberikan respon yang sangat baik bahwa kegiatan ini sangat menarik dan membantu mitra dalam menjalankan usahanya.

\section{Ucapan Terimakasih}

Terima kasih kepada Institut Teknologi dan Bisnis STIKOM Bali atas dukungan yang diberikan sehingga kegiatan pengabdian masyarakat ini dapat terlaksana dengan baik dan lancar.

\section{Daftar Pustaka}

Agatha, C., Tumbel, A., Soepeno, D., Sam, U., \& Manado, R. (2019). Pengaruh Brand Image Dan Electronic Word of Mouth Terhadap Minat Beli Konsumen Oriflame Di Manado. Jurnal EMBA: Jurnal Riset Ekonomi, Manajemen, Bisnis Dan Akuntansi, 7(1), 131-140. https://doi.org/10.35794/emba.v7i1.22291

Anggriani, R., Abdurrahman, A., \& Ibrahim, I. D. K. (2021). Pelatihan Strategi Pemasaran di Era New Normal pada Kalangan Mahasiswa Fakultas Ekonomi dan Bisnis Universitas Bumigora. ADMA: Jurnal Pengabdian Dan Pemberdayaan Masyarakat, 1(2), 91-98. https://doi.org/10.30812/adma.v1i2.1027

Arisandi, D., \& Pradana, M. N. R. (2018). Pengaruh Penggunaan Social Media Terhadap Brand Awareness Pada Objek Wisata Di Kota Batam. JMD: Jurnal Riset Manajemen \& Bisnis Dewantara, 1(2), 109-116. https://doi.org/10.26533/jmd.v1i2.263

Diaz, R. A. N., Harsemadi, I. G., Arini, N. W. S., Sulistyorini, E., \& Wedasari, N. L. N. M. (2019). Optimalisasi Pemasaran Melalui Brand Packaging Dan E-Commerce Sebagai Media Promosi Pia Sinar Bali. Prociding SENADIMAS, 331-336.

Erlyana, Y. (2018). Analisis Peranan Desain Kemasan Terhadap Brand Identity Dari Sebuah Produk Makanan Lokal Indonesia Dengan Studi Kasus: Produk Oleh-Oleh Khas Betawi 'Mpo Romlah'. National Conference of Creative Industry: Sustainable Tourism Industry for Economic Development Universitas, (September), 1079-1097.

Gede, L., Suwirmayanti, P., Hadi, R., Adi, P., Permana, G., Sukerti, N. K., ... Vijaya, C. (2021). Penambahan Desain Kemasan dan Varian Rasa, 3(2), 75-82.

Kemenkes. (2020). Final-Panduan-Gizi-Seimbang-Pada-Masa-Covid-19-1.Pdf. Panduan Gizi Seimbang Pada Masa Pandemi COVID-19.

Putri, D. R., Suniantara, I. K. P., \& Suardika, I. G. (2019). Peningkatan Mutu Dan Kemasan Produksi Urutan Bali Home Industry Kelompok Disabilitas Bengkala, Buleleng, Bali. Bhakti Persada, 5(2), 30-48. https://doi.org/10.31940/bp.v5i2.1476 


\section{ADMA}

Gurnal Pengabdian dan Pemberdayaan Masyarakat
2021, Vol.2, No.1, pp.1-10

Doi: 10.30812/adma.v2i1.1165

Saryanti, I. G. A. D., Mandasari, E., \& Sidhiantari, I. G. A. P. I. (2020). Pengembangan dan Pemanfaatan Desain Kemasan sebagai Media Promosi pada UKM Heavenine. Journal of Community and Development, 1(1), 1-5. https://doi.org/10.47134/comdev.v1i1.1

Semuel, H., \& Setiawan, K. Y. (2018). Promosi Melalui Sosial Media, Brand Awareness, Purchase. Manajemen Pemasaran, 12(1), 47-52. https://doi.org/10.9744/pemasaran.12.1.47 


\section{ADMA}

Gurnal Pengabdian dan Pemberdayaan Masyarakat
2021, Vol.2, No.1, pp.1-10

Doi: 10.30812/adma.v2i1.1165 